\section{ОБЛІКОВІ АСПЕКТИ ПРОЦЕДУРИ РЕОРГАНІЗАЦІЇ БАНКІВСЬКИХ УСТАНОВ ${ }^{\odot}$}

Н.М. ГУДЗЕНКО, кандидат економічних наук, доцент, доцент кафедри обліку та оподаткування в галузях економіки,

Н.I. КОВАЛЬ, кандидат економічних наук, доцент, доцент кафедри обліку та оподаткування в галузях економіки,

Т.М. КОРПАНЮК, кандидат економічних наук, доцент, доцент кафедри обліку та оподаткування в галузях економіки, Вінницький національний аграрний університет (м. Вінниця)

\footnotetext{
Розкриваються особливості реорганізачії банківських установ як одного із дієвих заходів уникнення банкрутства та стабілізації фінансового стану, звертається увага на необхідність поліпшення платоспроможності вітчизняних банків в умовах економічної та політичної нестабільності, світової фінансової кризи.
}

За результатами проведеного дослідження узагальнено всі види банкрутства за класифікаційними ознаками та виділено їх класифікацію в різних аспектах (правовому, контрольному, бухгалтерському) із врахуванням потреб бухгалтерського обліку, здійснення аналізу та складання відповідної звітності. Правовий аспект охоплює всі запропоновані види банкрутства, оскільки будь-який вид банкрутства стосується прав та інтересів юридччних і фізичних осіб. Проте не всі види банкрутства розглядаються з точки зору бухгалтерського обліку $i$ контролю.

У статті обтрунтовано перелік об'єктів обліку при різних видах реорганізації (злитті, приєднанні, перетворенні, оскільки процедура реорганізації включає операиії з прийняття на облік підприємств-правонаступників); акцентується увага на проблемах відображення в обліку розрахунків за претензіями та необхідності їх аналітичної деталізації, щзо розщирює інформачійні можливості реєстру вимог кредиторів, підвищує прозорість інформації для зовнішніх користувачів $i$ знижує ризик неплатежів.

Ключові слова: банкрутство, реорганізація, санація, платоспроможність, ліквідність, облік, аналітична оцінка, система звітних показників.

Табл.: 1. Рис.: 2. Літ.: 12.

${ }^{\circ}$ Н.М. ГУДЗЕНКО, Н.І. КОВАЛЬ, Т.М. КОРПАНЮК, 2019 
http://efm.vsau.org/

\title{
ACCOUNTING PROCEDURES FOR REORGANIZATION OF BANKING INSTITUTIONS
}

\author{
GUDZENKO Nataliya,
}

Candidate of Economic Sciences, Associate Professor, Associate Professor of the Department of Accounting and Taxation in the Fields of the Economy,

KOVAL Natalia, Candidate of Economic Sciences, Associate Professor, Associate Professor of the Department of Accounting and Taxation in the Fields of the Economy,

KORPANIUK Tetiana, Candidate of Economic Sciences, Associate Professor, Associate Professor of the Department of Accounting and Taxation in the Fields of the Economy, Vinnytsia National Agrarian University

(Vinnytsia)

The peculiarities of reorganization of banking institutions as one of the effective measures to avoid bankruptcy and to stabilize the financial state are revealed, attention is drawn to the need to increase the solvency of domestic banks in conditions of economic and political instability, the global financial crisis.

According to the results of the research, all types of bankruptcy are classified according to the classification criteria and their classification in different aspects (legal, control, accounting) is taken into account taking into account the requirements of accounting, the analysis and preparation of the corresponding reporting. The legal aspect covers all the proposed types of bankruptcy, because any type of bankruptcy concerns the rights and interests of legal entities and individuals. However, not all types of bankruptcy are considered in terms of accounting and control.

Since the reorganization procedure is a complex of actions involving transactions for the registration of successor enterprises, the article substantiates the list of objects of accounting for various types of reorganization (mergers, mergers, transformations); the focus is on the problems of displaying in the calculation of claims settlements and the need for their analytical detail, which expands the information capabilities of the register of claims of creditors, increases the transparency of information for external users and reduces the risk of non-payment.

Key words: bankruptcy, reorganization, sanation, solvency, liquidity, accounting, analytical estimation, system of reporting indicators.

Tabl.: 1. Fig.: 2. Ref.: 12.

\section{УЧЁТНЫЕ АСПЕКТЫ ПРОЦЕДУРЫ РЕОРГАНИЗАЦИИ БАНКОВСКИХ УЧРЕЖДЕНИЙ}

ГУДЗЕНКО Наталья Николаевна, кандидат экономических наук, доцент, доцент кафедры учёта и налогообложения в отраслях экономики,

КОВАЛЬ Наталия Ивановна, кандидат экономических наук, доцент, доцент кафедры учёта и налогообложения в отраслях экономики, 
КОРПАНЮК Татьяна Николаевна, кандидат экономических наук, доцент, доцент кафедры учёта и налогообложсения в отраслях экономики, Винницкий национальный аграрный университет (2. Винница)

Раскрываются особенности реорганизащии банков как одной из действенных мер предотвращения банкротства и стабилизации финансового состояния, обращается внимание на необходимость улучшения платежеспособности отечественных банков в условиях экономической и политической нестабильности, мирового финансового кризиса.

По результатам проведённого исследования обобщены все виды банкротства по классификачионным признакам и выделена их классификация в различных аспектах (правовом, контрольном, бухгалтерском) с учётом потребностей бухгалтерского учёта, осуществления анализа и составления соответствующей отчётности. Правовой аспект охватывает все предложенные виды банкротства, так как любой вид банкротства касается прав и интересов юридических и физических лич. При этом не все виды банкротства рассматриваются с точки зрения бухгалтерского учёта и контроля.

В статье обоснован перечень объектов учёта при различных видах реорганизации (слиянии, присоединении, преобразовании), поскольку процедура реорганизации предусматривает комплекс действий, который обобщает операции по принятию на учёт предприятий-правопреемников, акиентируется внимание на проблемах отражения в учёте расчётов по претензиям и необходимости их аналитической детализачии, что расширяет информационные возможности реестра требований кредиторов, повышает прозрачность информации для внешних пользователей и снижает риск неплатежей.

Ключевые слова: банкротство, реорганизация, санация, ликвидность, платежеспособность, учёт, аналитическая оценка, система отчётных показателей.

Табл.: 1. Рис.: 2. Лит.: 12.

Постановка проблеми. Аналіз стану вітчизняної банківської системи свідчить про те, що за роки незалежності вона є практично сформованою під впливом активного запровадження нових принципів діяльності банків, розробки та практичної реалізації системи банківського нагляду та управління, активного використання зарубіжного досвіду роботи банківської системи розвинутих країн. Банківська система є важливою складовою фінансово-кредитної системи держави.

Однак подальший розвиток економічних процесів, зростання рівня концентрації капіталу в різних галузях, розширення зовнішньоекономічних зв'язків, нестабільність фінансового ринку, викликана кризовими процесами, висувають нові вимоги до вже діючої банківської системи в цілому та фінансово-кредитних відносин зокрема.

Оцінка результативності діяльності банківської системи свідчить про те, що для реалізації основних завдань на фінансовому ринку більшість банків мають недостатній рівень капіталізації та ліквідності, надто вразливі до коливань на 
фінансово-кредитному ринку, мають суттєві недоліки в організації банківського менеджменту, управлінського обліку. Сукупність вищенаведених факторів призвела до того, що криза ще більше поглибила існуючі недоліки та призвела до банкрутства досить значної кількості банківських установ, які вважалися відносно стабільними. Решта банків, навіть маючи досить високі показники фінансової стабільності, знаходяться у стадії невизначеності, що ускладнює і без того складну ситуацію на фінансовому ринку.

Усі вищезгадані фактори зумовлюють необхідність пошуку можливостей удосконалення банківської системи, іiі реформування 3 метою приведення іï у відповідність до існуючих умов.

Частковому вирішенню проблем сприяло прийняття Закону «Про банки i банківську діяльність», де відображені рекомендації щодо реформування банківської системи, визначено шляхи реорганізації та реструктуризації комерційних банків шляхом запровадження тимчасових адміністрацій, порядок ліквідації та злиття банків.

Реорганізація та ліквідація банків є однією з основних проблем реформування вітчизняної банківської системи. Метою реструктуризації є фінансове оздоровлення проблемних банків, підвищення рівня їх ліквідності та капіталізації, запровадження тимчасової адміністрації в проблемних банках у стані фінансової скрути, удосконалення банківського менеджменту та звітності.

Усе вищезгадане зумовило актуальність обраної теми дослідження.

Аналіз останніх досліджень і публікацій. Дослідження особливостей реорганізації та відображення в обліку операцій, що її супроводжують, можливостей використання міжнародного досвіду в реформуванні банківської системи розглядали такі провідні вчені, як Білик О.І. [4], Васильчишин О.Б. [5], Вдовенко Л.О., Голов С.Ф., Дзюблюк О., Другов О.О. [6], Кучеренко Т.С., Крупка Я.Д., Легенчук С.Ф., Міщенко В. [7], Пушкар М.С., Руда О.Л., Созоник М. [10], Усач Б., Чурило П. Б.[11], Шевчук В.О. та ін.

Однак, незважаючи на проведені дослідження, достатньо повно розкриті процедура і механізм реорганізації, тоді як обліковий аспект процесу реорганізації банківських установ висвітлюється досить обмежено.

Формулювання цілей статті. Мета статті полягає у дослідженні необхідності реорганізації банківських установ, механізму іiі здійснення, облікових аспектів процедури реорганізації та банкрутства комерційних банків 3 метою розробки пропозицій $з$ удосконалення організації обліку, що забезпечить можливість формування інформації для прогнозування ризиків та можливості банкрутства.

Виклад основного матеріалу дослідження. Починаючи 32014 року, в Україні розпочався так званий «банкопад». Він був спричинений багатьма чинниками, зокрема політичними, економічними, соціальними, політикою Національного банку України щодо очищення банківської системи і не тільки. Дослідження процесів трансформації економіки України свідчить про те, що вітчизняній банківській системі доводиться постійно працювати в умовах нестабільності зовнішнього середовища, яке знаходиться в нестійкому фінансовому стані. Після відносної фінансової стабілізації в економіці нині спостерігається глибока криза. Існуюча економічна ситуація вимагає докорінних змін у структурі промислового виробництва, які повинні спрямовуватися на зростання галузей 3 високою доданою вартістю. Саме цей фактор має стати основою економічного зростання в майбутньому [1]. 
Незважаючи на те, що вітчизняний банківський сектор набагато слабший, ніж в розвинених країнах, він повинен стати однією з головних рушійних сил структурної перебудови галузей промисловості та сільського господарства. Для реалізації цього завдання необхідно побудувати міцну банківську систему, яка базується на стабільних банківських установах. У таких умовах особливої актуальності набуває вміння управляти фінансовою стійкістю банківських установ, вчасно виявляти ознаки нестабільності та банкрутства та, по можливості, намагатися їх нейтралізувати або ліквідувати.

Криза в банківському секторі проявилася в наступних негативних діях: вилученні грошових коштів вкладниками із депозитних рахунків, зниженні кількості клієнтів у проблемних банках, відтоці фінансового капіталу за кордон, переведення населенням запасів національної валюти в більш стабільну іноземну (долари, євро). Звичайно, такі явища не могли не позначитися на загальній економічній ситуації в країні, сприяли росту інфляції, зниженню темпів економічного росту.

Обов'язкова умова виживання банків у 2017-му році залишається незмінною виконання графіка капіталізації, узгодженого Нацбанком 3 МВФ. Великим фінансовим установам за рахунок вливань від акціонерів доводиться покривати збитки від неякісних кредитних портфелів, а більш дрібним - просто дотягувати свої капітали до нормативних значень. До 11 липня на ринку не повинно залишитися банків, чий статутний капітал буде становити менше 200 млн гривень. Сьогодні цій вимозі не відповідають 48 банків [2].

Однією з причин ліквідації банківських установ у 2017 році є не тільки погіршення їх платоспроможності, а й втрата інтересу до таких установ з боку їх власників та засновників. Тому сфера банківського бізнесу в нинішніх умовах $\epsilon$ не настільки привабливою і заробляти в банківському бізнесі сьогодні досить складно. Ситуація ускладнена тим, що депозити в систему повертаються повільно, а кредитний портфель при цьому скорочується. За 11 місяців минулого року, за даними НБУ, він зменшився на 16 млрд грн. - до 786 млрд. грн. Одночасно посилюються вимоги банківського нагляду. При цьому фінансове становище акціонерів банків останніми роками поступово погіршується. Усі ці умови в комплексі призвели до того, що у 2016 році про самоліквідацію заявили відразу 4 банки: «Фінанс Банк», «Фінекс», «Інвестиційно-трастовий банк» i «Народний капітал». Щодо банку «Народний капітал», то склалася ситуація, за якої НБУ передав його Фонду гарантування вкладів [2].

Кількість закритих державою банків до січня 2017 р. склала 148. У результаті банкрутства установ (табл. 1) мільйони українців втрачають свої накопичення.

Таблиия 1

Виведення банків з ринку протягом 2015-2017 pp.

\begin{tabular}{|c|c|}
\hline Назва банку & Термін здійснення \\
\hline 1 & 2 \\
\hline \multicolumn{2}{|l|}{ Банки з тимчасовою адміністрачією } \\
\hline ПАТ «Банк «ЮНІСОН» & 328 квітня 2016 р. \\
\hline АТ «РОДОВІД Банк» & 326 лютого 2016 р. \\
\hline ПАТ «КБ «Фінансова ініціатива» & 324 червня 2015 p. \\
\hline \multicolumn{2}{|l|}{ Банки, щео ліквідуються } \\
\hline ПАТ «Комерційний банк «Гефест» & 2 жовтня 2017 р. - 1 жовтня 2018 р. \\
\hline АКБ «Новий» & 1 вересня 2017 p. - 31 серпня 2019 р. \\
\hline
\end{tabular}


Продовження табл. 1

\begin{tabular}{|c|c|}
\hline 1 & 2 \\
\hline ПАТ «ДіамантБанк» & 24 червня 2017 р. - 23 червня 2019 р. \\
\hline ПАТ «ФІНБАНК» & 28 квітня 2017 р. - 27 квітня 2019 р. \\
\hline ПАТ «ВекторБанк» & 22 березня 2017 р. - 21 березня 2019 р. \\
\hline АТ «НК Банк» & 9 березня 2017 р. - 8 березня 2019 р. \\
\hline ПАТ «Платинум Банк» та ін. & 24 лютого 2017 р. - 23 лютого 2019 р. \\
\hline \multicolumn{2}{|l|}{ Банки, продані інвесторам } \\
\hline ПАТ «Астра Банк» & \\
\hline \multicolumn{2}{|l|}{ Банки, продані державі } \\
\hline ПАТ «КБ «ПРИВАТБАНК» & \\
\hline \multicolumn{2}{|l|}{ Банки, вкладникам яких здійснювалися виплати } \\
\hline $\begin{array}{l}\text { ПАТ «АКБ «Базис», ПАТ «Банк «Столиця», } \\
\text { ПАТ «КБ «Соцком Банк», } \\
\text { ПАТ «КБ «Володимирський», } \\
\text { ТОВ «Діалогбанк» та ін. }\end{array}$ & \\
\hline
\end{tabular}

Джерело: систематизовано за даними НБУ

На момент завершення 2018 р. в Україні зареєстровано 77 діючих банків. Їх кількість зменшилася на 4 порівняно із попереднім кварталом за рахунок того, що 2 закінчили процедури злиття, один банк перетворений на фінансову компанію, а ВТБбанк визнано неплатоспроможним. Частка ринку державних фінансових установ залишається практично незмінною і становить $54.7 \%$ та $63.4 \%$ за чистими активами та депозитами населення відповідно.

Щоразу банківська криза несе удар для бізнесу і населення, які працювали зі збанкрутілими банками. На жаль, в Україні сформувалася така банківська система, яка дає змогу багаторазово залишати громадян без заощаджень.

Серйозного удару вітчизняній банківській системі завдало керівництво НБУ в межах здійснення програми так званого очищення банківського сектору. Внаслідок цього питома вага «поганих боргів» у загальному обсязі активів зросла 3 12,9\% у 2013 р. до 30,45\% у 2016 р. Протягом 2017-2018 pр. банківська система поступово повертає втрачений фінансовий ресурс. Жорстка вимога НБУ щодо необхідності швидкого впровадження революційно нового для банків МСБО-9 «Фінансові інструменти» та інших європейських директив сприяла відсіканню існуючого українського корпоративного бізнесу від кредитних ресурсів. Найбільш революційною відмінністю $є$ необхідність формування резервів під знецінення фінансових активів на основі очікуваних кредитних збитків. Очікується, що резерви за безнадійною заборгованістю збільшаться в розмірі, будуть більш мінливими.

За період дії програми «очищення банківського сектору» припинили роботу 77 комерційних банків, у результаті без роботи залишилися понад 35 тис. банківських працівників. За даними Мінфіну в закритих банках залишалося депозитів вкладників на суму 163 млрд грн (орієнтовно 6,5 млрд дол), з них частка вкладів фізичних осіб становила 111 млрд грн, і 52 млрд грн належить бізнесу [1]. В Україні за період з 2012 по 2017 р. 96 банків було визнано банкрутами, 85 з них ліквідовано з подальшою виплатою компенсації вкладникам. Під загрозою закриття опинилися банки 3 російським капіталом. Головними їхніми проблемами є висока доларизація (в умовах курсової нестабільності банківським установам складніше виконувати свої зобов'язання), високий рівень прострочених кредитів. За даними НБУ та Мінфіну 


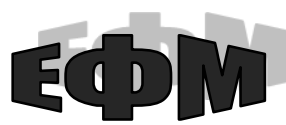

http://efm.vsau.org/

протягом 2012-2013 рр. ФГВФО забезпечував виплати по 2-х банківських установах. У 2014 р. аналогічна проблема виникла вже з 33 фінансовими установами. Протягом 2015 р. 33 банки мали проблеми 3 виплатами депозитних вкладів. За період 20162017 рр. кількість проблемних фінансових установ становила 19 у 2016 р. та 9 у 2017 p. У 2014-2018 pp. масово скорочувались відділення Ощадбанку та ПриватБанку: за період з 1 квітня по 1 жовтня 2018 р. кількість банківських відділень зменшилася з 9,440 тис. до 8,750 тис. (Ощадбанк закрив 383 відділень, Приватбанк 177, а Укрсоцбанк - 65).

Фонд гарантування вкладів намагався знайти інший шлях вирішення проблем у проблемних банках, проте це йому вдалося лише в 11 випадках. Так один банк був націоналізований - це ПриватБанк. Через націоналізацію Привату частка держави на фінансовому ринку досягла історичного максимуму. Близько 54\% активів усіх українських банків тепер контролює Мінфін. Ще два банки вдалося продати інвесторам, у двох фінансових установах вдалося створити перехідні банки, у 5 випадках фонду вдалося передати активи і зобов'язання іншим установам.

Фонд гарантування вкладів фізичних осіб зміг компенсувати лише трохи менше, ніж половина суми внесків у закритих банках на суму 80 млрд грн, або понад 3 млрд дол. Водночас власні кошти Фонду гарантування вкладів становили лише 14 млрд грн, або трохи більше, ніж півмільярда доларів. Понад 60 млрд грн, або приблизно 2,5 млрд дол, надійшло на компенсацію втрачених депозитів із державного бюджету. Ці витрати тим самим, по-перше, погіршили фінансовий стан бюджету, а по-друге, створили несправедливий розподіл фінансових ресурсів, які були зароблені одними громадянами, але державою були передані іншим [1].

За період «очищення» понад 1,5 млн людей були змушені отримувати свої депозити через систему компенсації внесків. Через девальвацію гривні (з 8 до приблизно 28 гривень за долар) внески громадян за два роки знецінилися приблизно втричі. Втім невиплаченими залишаються понад 30 млрд грн (понад 1,2 млрд дол). Левову частку цієї суми вкладникам виплачено не буде. Кількість постраждалих вкладників перевищує 1 млн осіб. Втрата заощаджень в умовах різкого зниження рівня життя істотно погіршила соціально-політичну ситуацію в країні.

Керівництво НБУ подає факт скорочення кількості банків як своє особливе досягнення, внаслідок якого українські показники щільності банківської системи нібито наближаються або до середньосвітових, або, навіть, до світових зразків. Правильна політика банку полягає в залученні нових клієнтів, що веде до зростання дешевих ресурсів банку, в належній роботі з формування стабільної частини ресурсів банку за рахунок залучення такого перспективного виду ресурсів, як депозити фізичних осіб. Згідно з даними Нацбанку з початку цього року громадяни отримали кредитів лише на 3,6 млрд грн, що фактично дає змогу говорити про «замороження» ринку споживчого кредитування [2].

Слід зазначити, що банкрутство банків має місце і в економічно розвинених країнах, тобто притаманне для економік різних країн світу [2]. Дослідження Управління валютного контролю щодо банкрутства комерційних банків США визначило перелік основних факторів, що призвело до їх обвалу:

- погана якість активів - 98 \% банкрутств;

- недоліки в плануванні діяльності та політики їх управління - 90 \%;

- зловживання інсайдерів - 35 \%; 
- нестабільна економічна ситуація - $35 \%$;

- відсутність ефективної системи аудиту і контролю - 25 \%;

- шахрайство та зловживання в обліку - $11 \%$;

- незабезпечені витрати - 9\%.

Аналізуючи погану якість банківських активів, у результаті дослідження спеціалісти виявили 8 видів неспроможної практики управління портфелем кредитів та інвестицій в банках США, що збанкрутували [2]:

1) лібералізм при наданні кредитів - 85\%;

2) значні недоліки у фінансовій звітності - 79\%;

3) надлишкове кредитування - $73 \%$;

4) неповна документація у сфері оподаткування - 67\%;

5) кредитування під заставу товарів та цінних паперів - 55\%;

6) необгрунтована чисельність персоналу - 52\%;

7) висока концентрація негарантованих кредитів - 37\%;

8) кредитування за межами своєї зони - $23 \%$.

Згідно з чинним законодавством комерційний банк, як юридична особа, може припинити свою діяльність шляхом реорганізації або ліквідації.

Реорганізація передбачає правонаступництво однієї юридичної особи за всіма майновими правами та зобов'язаннями (під час злиття, приєднання, перетворення) або частиною майнових прав і зобов'язань (під час виділення, поділу) іншій юридичній особі [3].

Ліквідація - це припиненням діяльності суб'єкта господарювання, визнаного господарським судом банкрутом, 3 метою здійснення заходів щодо задоволення визнаних судом вимог кредиторів шляхом продажу його майна.

Під процедурою припинення діяльності банку слід розуміти логічно витриману, сувору послідовність реалізації дій з виконання етапів припинення діяльності юридичної особи від подання заяви про банкрутство до суду або укладання договору про реорганізацію до внесення запису про створення або припинення юридичної особи в ЄДРПОУ. Ліквідаційна процедура може здійснюватися у добровільному порядку, коли подальше існування підприємства визнано недоцільним (наприклад, за рішенням засновників або акціонерів), або в примусовому порядку [4].

Реструктуризація банків є надзвичайно складною процедурою та відрізняється від аналогічної процедури у підприємницькій діяльності. Під реструктуризацією в банківській системі розуміють комплекс заходів, які передбачають поліпшення фінансової стійкості банківської системи, підвищення ліквідності та платоспроможності з урахуванням змін у національній макросистемі, на світовому ринку через створення нових банків та реорганізацію вже діючих, зміну юридичного статусу існуючих банківських установ або їх закриття [2].

Реструктуризація - це безперервний процес підвищення фінансової стабільності банківської установи за допомогою впровадження комплексу внутрішніх заходів щодо адаптації системи управління до ринкових умов, що постійно змінюються.

Виділяють наступні види реструктуризації: кредитної системи; системи кредитних організацій; банківської системи. Реструктуризація кредитної організації - це зміна структури її активів і пасивів, внутрішньої організаційної побудови, які 
мають сприяти подоланню фінансової нестабільності даної кредитної організації, відновити ії платоспроможність. Реструктуризація системи кредитних організацій це, в першу чергу, зміна співвідношення банків та небанківських кредитних установ, співвідношення універсальних та спеціалізованих банків, яка спрямована на відновлення здатності системи виконувати свої функції [4].

Об'єктивними передумовами реорганізації є: формування та розвиток ринкових відносин, забезпечення стабільності роботи банківської системи, зміна форми власності, необхідність виконання банками вимог законодавства, забезпечення платоспроможності та ліквідності комерційних банків.

Головною метою реорганізації комерційних банків повинно бути підвищення надійності та стійкості банківської системи, забезпечення належного рівня капіталізації банків, захист інтересів кредиторів та вкладників, поліпшення фінансового стану комерційних банків, розширення спеціалізації, переорієнтації діяльності банків та зростання довіри до них [5].

При реорганізації проблемних банків необхідно передбачити, що новоствореному банку ліцензія на здійснення банківської операції з залучення депозитних коштів фізичних осіб надається за умови відсутності в його портфелі сумнівних та безнадійних кредитів, не покритих резервами. Реорганізація банків пов'язана 3 поглибленням розподілу праці i може здійснюватися 3 метою поглиблення спеціалізації та універсалізації банків. Універсальні банки більш мобільні, та мають можливості здійснювати прибуткову діяльність в умовах економічної нестабільності.

Основні методологічні принципи реорганізації комерційних банків, відповідно до затвердженої Стратегії НБУ щодо реструктуризації та реорганізації банків у стані фінансової скрути №502, затвердженої Правлінням НБУ від 01.12.98р., можна представити на рис. 1.

\begin{tabular}{|c|c|}
\hline & Методологічні принципи реорганізації комерційних банків \\
\hline & $\begin{array}{l}\text { пріоритетність інтересів суспільства, банківської системи та вкладників перед інтересами } \\
\text { комерційного банку }\end{array}$ \\
\hline & $\begin{array}{l}\text { досягнення сегеративності (результативні показники діяльності новостворених банків } \\
\text { повинні бути кращі, ніж банків, що реорганізовуються) }\end{array}$ \\
\hline$\rangle$ & підвищення фінансової стійкості банків \\
\hline$\rangle$ & забезпечення безперервної роботи банків, які реорганізовуються \\
\hline$\rangle$ & $\begin{array}{l}\text { здатність банків, що беруть участь у реорганізації, виконувати вимоги НБУ щодо } \\
\text { формування статутного капіталу, дотримуватись економічних нормативів, забезпечувати } \\
\text { прибуткову діяльність }\end{array}$ \\
\hline
\end{tabular}

\section{Рuc. 1. Принципи реорганізації комерційних банків}

Джерело: Стратегія НБУ щодо реструктуризаџї та реорганізаџї̈ банків у стані фінансової скрути [6] 


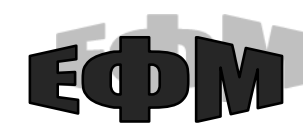

http://efm.vsau.org/

За змістом форма реорганізації може бути об'єднувальною, розподільчою, також реорганізація може здійснюватися шляхом перетворення. До об'єднувальних форм належать злиття та приєднання. Відповідно до ст. 26 Закону України «Про банки і банківську діяльність» злиття передбачає припинення діяльності окремих комерційних банків як юридичних осіб та передачу майнових прав і зобов'язань цих банків до новоствореного банку. Приєднання передбачає припинення діяльності комерційного банку як юридичної особи та передачу усіх майнових прав і зобов'язань до іншого комерційного банку на правах філії чи без ії відкриття [7]. До розподільчих форм реорганізації можна віднести поділ та виділення. Поділ передбачає припинення діяльності комерційного банку як юридичної особи та передачу за розподільчим актом у визначених частинах усіх його майнових прав і зобов'язань до кількох новостворених комерційних банків. Виділення передбачає створення комерційного банку (або декількох комерційних банків), до якого (яких) за розподільчим актом у відповідних частинах переходять майнові права і зобов'язання банку, що реорганізовується [7].

Період закінчення реорганізації впливає на ії відображення в бухгалтерському обліку. Банк-правонаступник під час процедури приєднання може відображати записи на рахунках бухгалтерського обліку лише 3 дати внесення запису про припинення діяльності банку-правопопередника. А в ході перетворення, злиття, виділення та поділу банки-правонаступники роблять записи в бухгалтерському обліку після їх реєстрації.

Особливості процедури банкрутства визначає розділ V «Тимчасова адміністрація та ліквідація банків» Закону України «Про банки і банківську діяльність». Банкрутству банку звичайно передують процедури санації, призначення Національним банком України тимчасового адміністратора, завданням якого $є$ виведення фінансової установи з кризового становища. Усі ці заходи можуть тривати від 6 місяців до року [7].

Процедура реорганізації є досить складною за механізмом здійснення та відображення в обліку і залежить від того, на яких умовах буде здійснюватися реорганізація (який статус отримає в подальшому фінансово-кредитна установа). Перед вирішенням питань, пов'язаних із організацією бухгалтерського обліку, особливу увагу необхідно приділити уточненню системи документообігу [8].

Для того, щоб здійснити реорганізацію у формі злиття або приєднання необхідно послідовно пройти основні етапи, наведені на рис. 2.

Об’єктом обліку під час процедури реорганізації виступають операції, пов'язані з проведенням цієї процедури. Під час об'єднання банківських установ необхідно об'єднувати залишки майнових прав та зобов'язань усіх банківправопопередників.

На практиці виникає проблема складності об'єднання залишків на рахунках бухгалтерського обліку шляхом перенесення даних аналітичного обліку правопопередника до системи бухгалтерського обліку правонаступника. Пропонуємо виділити комплекс заходів, які слід здійснювати одночасно:

- об'єднання залишків за аналітичними рахунками шляхом внесення додаткових записів до регістрів бухгалтерського обліку банку-правонаступника;

- введення до робочого плану рахунків банку-правонаступника нових субрахунків i аналітичних рахунків для обліку активів i пасивів банкуправопопередника, якщо у банку-правонаступнику до початку реорганізації не відкрито аналітичних рахунків для відповідних об'єктів обліку, які передаються у 
складі майна та зобов'язань. Зазначені процедури пов'язані з відображенням операцій в обліку, що є наступним після закінчення реорганізації. Слід зауважити, що момент закінчення процедури реорганізації в юридичному аспекті не збігається 3 моментом завершення реорганізації під час відображення в бухгалтерському обліку та визначенні об'єктів оподаткування. Тому законодавство не обмежує можливості завершення бухгалтерських процедур з об'єднання облікових даних реорганізованих юридичних осіб після закінчення реорганізації.

\begin{tabular}{|c|} 
Етапи здійснення реорганізації фінансово-кредитної установи \\
$\begin{array}{c}\text { Ухвалення рішення Загальними зборами банківської установи- } \\
\text { правопопередника про реорганізацію у формі злиття або приєднання, про } \\
\text { затвердження договору реорганізації і про затвердження передавального акта }\end{array}$ \\
Реєстрація підприємства-правонаступника \\
Затвердження Статуту та обрання ради директорів банківської установи- \\
правонаступника
\end{tabular}

Рис. 2. Основні етапи проведення процедури реорганізації фінансово-кредитної установи шляхом злиття або присднання Джерело: узагальнено за даними [4]

Оскільки під час реорганізації в більшості випадків змінюється організаційноправова форма банківської установи, обов'язкові зміни відбудуться в організації його обліку. В ході реорганізації правонаступнику можуть передаватися і не всі майнові права та зобов'язання, а будь-яка їх частина (під час виділення та поділу).

Оскільки виділення передбачає розподіл майна (активів та пасивів банківської установи), цей процес в обов'язковому порядку повинен супроводжуватися проведенням інвентаризації майна банку, що реорганізується та складанням розподільчого балансу. Очевидно, що виділення нової фінансової установи вимагає підготовки та внесення змін і доповнень до установчих документів банку, з якого здійснюється виділення. Цей процес не відрізняється від процедури уточнення засновницьких документів [9].

Оскільки під час реорганізації шляхом поділу банк-правопопередник перестає існувати, даний спосіб реорганізації вимагає не лише серйозних організаційних заходів, але й додаткових фінансових витрат. Так, наприклад, якщо банк-правопопередник використовував відповідні ліцензії на здійснення діяльності, то під час поділу банкправонаступник має пройти процес отримання нових ліцензій. У випадку виділення ліцензії залишаються у банку-правопопереднику. Додаткові операції, пов'язані із отриманням нових ліцензій, обов'язково повинні відображатися в обліку.

Особливу увагу під час реорганізації шляхом виділення та поділу необхідно приділяти організації роботи бухгалтерського апарату, який створюється у банкуправонаступнику. Йому необхідно прийняти на облік майно, що передається за 


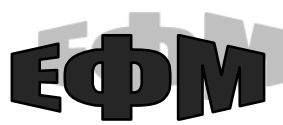

http://efm.vsau.org/

розподільчим балансом, відкрити облікові регістри, організувати облік господарських операцій, виконати інші обов'язкові процедури, що супроводжують процес початку діяльності нових юридичних осіб.

Щодо розподілу майна між учасниками процедури реорганізації шляхом виділення та поділу, слід відзначити наступне: необхідно враховувати, що майно розподіляється не між учасниками, а між юридичними особами, оскільки майно банку належить йому як юридичній особі. Розподіл майна банку здійснюється, як правило, виходячи із частки учасників у його статутному капіталі. Не виключається варіант домовленості між учасниками. Якщо в результаті поділу статутного капіталу його виявиться недостатньо для формування статутного капіталу реорганізованої фінансової установи в розмірах, встановлених законодавством, засновники повинні здійснити додаткове внесення вкладів у визначеному розмірі або пропорційно своїй частці в капіталі.

Нестабільність банківської системи України та кризові явища в економіці призвели до масової збитковості та втрати ліквідності багатьох фінансово-кредитних установ. Окремі з них балансують на межі банкрутства, за яким може слідувати і ліквідація. Тому в умовах високого ризику лише добре організована підсистема управлінського обліку здатна задовольнити потреби в оперативній інформації, збільшити можливості керівництва регулювати економічні процеси в банку [10].

Висновки. Підсумовуючи результати дослідження, запропоновано найбільш оптимальну класифікацію процедур реорганізації фінансово-кредитних установ банківського типу за різними ознаками із врахуванням завдань бухгалтерського обліку, а саме: за наявністю змін майна та зобов'язань, за збереженням банкуправопопередника, за моментом закінчення процедури реорганізації. Перспективним напрямом $є$ удосконалення організації управлінського обліку з використанням системного підходу - облікове забезпечення процесу реорганізації має розглядатися в сукупності з формуванням відповідної методології, ефективного менеджменту та сучасних інформаційних технологій. Облікова політика повинна забезпечити можливість формування в обліку інформації для прогнозування ризиків та можливості банкрутства комерційного банку.

\section{Список використаних джерел}

1. Банківський нагляд. Фінансовий стан банків України. Національний банк України: веб-сайт. URL: www.bank.gov.ua (дата звернення: 25.11.2018).

2. Аналітичний огляд банківської системи України за І кв. 2018 р. НРА «Рюрик». Національне агентство «Рюрик»: веб-сайт. URL: http://rurik.com.ua/ documents/ research/bank_system_tendency_1_kv_2018_ukr.pdf (дата звернення: 23.11.2018).

3. Банківська система України: становлення і розвиток в умовах глобалізації економічних процесів / за ред.. д.е.н., проф. О. В. Дзюблюка. Тернопіль: Астон, 2012. 358 с.

4. Білик О. І. Проблеми та перспективи проведення реорганізації як способу оздоровлення банківської системи України. Фінансовий простір. 2015. № 1 (17). URL: http://fp.cibs.ubs.edu.ua/files/1501/15boiptp.pdf (дата звернення: 23.11.2018).

5. Другов О.О. Прийма О. В. Реструктуризація банківської системи України: сучасний стан та перспективи. Фінансовий простір. 2015. №4(20). С. 40-48.

6. Стратегія НБУ щодо реструктуризації та реорганізації банків у стані фінансової скрути від 01.12 .98 p. №502/ Правління НБУ. URL: https://zakon.rada.gov.ua/laws/show/v0502500-98 (дата звернення: 23.11.2018). 
7. Про банки й банківську діяльність: Закон України від 7.122000 р. №2121III. URL: www.rada.gov.ua (дата звернення: 23.11.2018).

8. Васильчишин О. Б. Злиття та поглинання в банківській системі України. Scientific Journal «ScienceRise». 2015. №6/3(11). C. 43-50. URL: file://C:/Users/admin /Downloads/texc_2015_6(3) 10\%20(1).pdf (дата звернення: 23.11.2018).

9. Чурило П. Б. Оцінка вартості банку в аспектах злиття та поглинання. Економічний простір. 2010. № 41. С. 171-183.

10. Міщенко В. Петріна А. Міжнародний досвід реструктуризації банківської системи за участі держави. Вісник Національного банку Украӥни. 2011. № 4. С.12-17.

11. Офіційний сайт Національного банку України. веб-сайт. URL: http://www.bank.gov.ua (дата звернення: 23.11.2018).

12. Созоник М. Злиття і поглинання на банківському ринку. Золотий резерв. 2011. № 5. C. 20-21.

\section{References}

1. Bankivskij nahlyad. Finansovij stan bankiv Ukrayiny [Bank supervision. Financial state of banks of Ukraine]. (n.d.). base bank.gov.ua. Retrieved from: http: www.bank.gov.ua/ [in Ukrainian].

2. Analitichnij oglyad bankivskoyi sistemi Ukrayini za I kv. 2018 r. [Analytical review of the banking system of Ukraine for the I quarter 2018]. (n.d.). base rurik.com.ua. Retrieved from: http:// rurik.com.ua / documents/research/bank_system_tendency_1_kv_2018_ukr.pdf [in Ukrainian].

3. Dzyublyuk. O.V. (Eds.). (2012). Bankivska sistema Ukrayini: stanovlennya i rozvitok $\mathrm{v}$ umovah globalizaciyi ekonomichnih procesiv [Banking system of Ukraine: becoming and development in the conditions of globalization of economic processes]. Ternopil, «Aston» [in Ukrainian].

4. Bilyk O.I. (2015). Problemy ta perspektyvy provedennia reorhanizatsii yak sposobu ozdorovlennia bankivskoi systemy Ukrainy [Problems and perspectives of reorganization as a way to improve the banking system of Ukraine]. Finansovyi prostir Financial passage, 1(1), 25-32. Retrieved from: http://fp.cibs.ubs.edu.ua /files/ 1501/15boiptp.pdf [in Ukrainian].

5. Drygov O.O. (2011), Restrukturyzatsiia bankivskoi systemy Ukrainy: suchasnyi stan ta perspektyvy [Restructuring of the Ukrainian banking system: current state and prospects], Finansovyi prostir - Financial space. 4 (20), pp. 40-48 [in Ukrainian].

6. Stratehiia NBU shchodo restrukturyzatsii ta reorhanizatsii bankiv u stani finansovoi skruty vid 01.12.98 r. №502 [NBU Strategy for Restructuring and Restructuring of Banks in the Situation of Financial Trouble]. (n. d.). zakon.rada.gov.ua. Retrieved from: https://zakon.rada.gov.ua/laws/show/v0502500-98 [in Ukrainian].

7. Zakon Ukrainy «Pro banky y bankivsku diialnist» [The Law of Ukraine «About banks and banking»]. (n. d.). .rada.gov.ua Retrieved from: www.rada.gov.ua [in Ukrainian].

8. Vasylchyshyn O.V. ( 2015). Zlyttia ta pohlynannia v bankivskii systemi Ukrainy [Mergers and acquisitions in the banking system of Ukraine]. Scientific Journal «ScienceRise», 11. Retrieved from: file://C:/Users/admin/Downloads/ texc_2015_6(3) 10\%20(1).pdf [in Ukrainian].

9. Chyrulo P.B. (2010). Otsinka vartosti banku v aspektakh zlyttia ta pohlynannia [Bank valuation in merger and acquisition]. Ekonomichnyi prostir - Economic space. 41, pp. 171-183 [in Ukrainian]. 


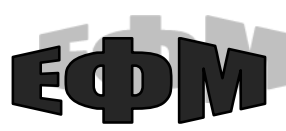

http://efm.vsau.org/

10. Mischenko V. (2011). Mizhnarodnyi dosvid restrukturyzatsii bankivskoi systemy za uchasti derzhavy [International experience of restructuring the banking system with the participation of the state]. Visnyk Natsionalnoho banku Ukrainy - Bulletin of the National Bank of Ukraine, 4, pp. 12-17 [in Ukrainian].

11. Ofitsiinyi sait Natsionalnoho banku Ukrainy [Official site of the National Bank of Ukraine]. Retrieved from: http://www.bank.gov.ua [in Ukrainian].

12. Sozony M. (2011). Zlyttia i pohlynannia na bankivskomu rynku [Mergers and acquisitions in the banking market]. Zolotyi rezerv-Gold reserve, 11, pp. 20-21 [in Ukrainian].

\section{Відомості про авторів}

ГУДЗЕНКО Наталія Миколаївна - кандидат економічних наук, доцент, доцент кафедри обліку та оподаткування в галузях економіки, Вінницький національний аграрний університет (21008, м. Вінниця, вул. Сонячна, 3, e-mail: gudzenko_nm@i.ua).

КОВАЛЬ Наталія Іванівна - кандидат економічних наук, доцент, доцент кафедри обліку та оподаткування в галузях економіки, Вінницький національний аграрний університет (21008, м. Вінниця, вул. Сонячна, 3, e-mail: Natkov@i.ua).

КОРПАНЮК Тетяна Миколаївна - кандидат економічних наук, доцент, доцент кафедри обліку та оподаткування в галузях економіки, Вінницький національний аграрний університет (21008, м. Вінниця, вул. Сонячна, 3, e-mail: tsharko@ukr.net).

GUDZENKO Nataliya - Candidate of Economic Sciences, Associate Professor, Associate Professor of the Department of Accounting and Taxation in the Fields of the economy, Vinnytsia National Agrarian University (21008, Vinnytsia, 3 Soniachna str., email: gudzenko_nm@i.ua).

KOVAL Natalia - Candidate of Economic Sciences, Associate Professor of the Department of Accounting and Taxation in the Fields of the Economy, Vinnytsia National Agrarian University (21008, Vinnytsia, 3 Soniachna str., e-mail: Natkov@i.ua).

KORPANIUK Tetiana - Candidate of Economic Sciences, Associate Professor, Associate Professor of the Department of Accounting and Taxation in the Fields of the Economy, Vinnytsia National Agrarian University (21008 Vinnytsia, 3 Soniachna str., email: tsharko@ukr.net).

ГУДЗЕНКО Наталья Николаевна - кандидат экономических наук, доцент, доцент кафедры учёта и налогообложения в отраслях экономики, Винницкий национальный аграрный университет ( 21008, г. Винница, ул. Солнечная, 3, e-mail: gudzenko_nm@i.ua).

КОВАЛЬ Наталия Ивановна - кандидат экономических наук, доцент, доцент кафедры учёта и налогообложения в отраслях экономики, Винницкий национальный аграрный университет ( 21008, г. Винница, ул. Солнечная, 3, e-mail: Natkov@i.ua ).

КОРПАНЮК Татьяна Николаевна - кандидат экономических наук, доцент, доцент кафедры учёта и налогообложения в отраслях экономики, Винницкий национальный аграрный университет $(21008$, г. Винница, ул. Солнечная, 3, e-mail: tsharko@ukr.net). 